JPPKMI 2 (1) (2021) 37-48
JURNAL PENELITIAN DAN PENGEMBANGAN
KESEHATAN MASYARAKAT INDONESIA
Jttps://journal.unnes.ac.id/sju/index.php/jppkmi

\title{
Analisis Upaya Peningkatan Mutu Pelayanan dengan Penerapan Metode Total Quality Management (TQM) di RS X
}

\author{
Kurnia Deswita $^{1} \bowtie$, Herman Sudirman $^{2}$, Sri Widodo $^{2}$ \\ ${ }^{1}$ Ilmu Kesehatan Masyarakat, Universitas Respati Indonesia, Indonesia \\ ${ }^{2}$ Rumah Sakit X
}

Info Artikel

Sejarah Artikel:

Diterima 24 April 2021

Disetujui 12 Juni 2021

Dipublikasi 21 Juni 2021

\section{Keywords:}

Quality Improvement,

Service, and TQM.

\section{URL:}

https://iournal.unnes.ac.i d/sju/index.php/ippkmi /article/view/47561

\begin{abstract}
Abstrak
TQM merupakan salah satu konsep manajemen modern yang berusaha untuk merespon secara tepat terhadap setiap perubahan yang ada. Metode TQM merupakan metode yang dijalankan dalam upaya peningkatan kualitas, salah satunya dalam kinerja rumah sakit dalam peningkatan mutu pelayanan. Tujuan umum pada penelitian ini adalah menganalisis bagaimana penerapan metode TQM dalam upaya peningkatan mutu pelayanan di RS X tujuan khusus dari penelitian ini adalah menganalisis bagaimana dukungan manajemen rumah sakit dalam implementasi 10 unsur TQM, menganalisis bagaimana implementasi metode TQM ditinjau dari 10 unsur pokok implementasi TQM, dan menganalisis bagaimana kepuasan pelanggan terhadap kualitas pelayanan ditinjau dari tangible, reability, responsiveness, emphaty, dan assurance. Untuk penelitian ini dilakukan di RS X dengan jumlah informan 10 orang. Penentuan informan ini dengan teknik snowball sampling. Hasil penelitian ini adalah dukungan manajemen dalam upaya peningkatan kualitas pelayanan telah dilakukan secara penuh, dari 10 unsur penerapan Total Quality Management (TQM) hanya unsur komitmen jangka panjang dalam hal sosialisasi rencana strategis belum dilakukan secara optimal, penerapan sepuluh karakteristik TQM menjadi indikasi pelayanan yang baik yang diberikan oleh Rumah Sakit X dengan senantiasa memberikan pelayanan sesuai dengan harapan dan keinginan pasien.
\end{abstract}

\begin{abstract}
TQM is one of the modern management concepts that strives to respond appropriately to any changes. TQM method is a method that is carried out in an effort to improve the quality, one of which is in the performance of hospitals in improving the quality of services. The general purpose of this study is to analyze how the implementation of TQM method in efforts to improve the quality of service in RS X the specific purpose of this study is to analyze how hospital management support in the implementation of 10 elements of TQM, analyze how the implementation of TQM method is reviewed from 10 main elements of TQM implementation, and analyze how customer satisfaction to service quality is reviewed from tangible, reability, responsiveness, emphaty, and assurance. For this study was conducted in $R S X$ with the number of informants 10 people. Determination of this informant with snowball sampling technique. The result of this study is management support in efforts to improve the quality of service has been done in full, from 10 elements of the implementation of Total Quality Management (TQM) only elements of long-term commitment in terms of socialization of strategic plans have not been carried out optimally, the application of ten characteristics of TQM is an indication of good service provided by Hospital $X$ by always providing services in accordance with the expectations and desires of patients.
\end{abstract}

(C) 2021 Universitas Negeri Semarang

Alamat korespondensi:

J1. Bambu Apus I No.3, Bambu Apus, Kec. Cipayung, Kota

Jakarta Timur, Daerah Khusus Ibukota Jakarta 13890

E-mail: kurniadeswita465@gmail.com 


\section{PENDAHULUAN}

Pelayanan kesehatan yang baik, saat ini menjadi suatu kebutuhan masyarakat untuk mendapatkan fasilitas kesehatan yang sesuai dengan finansial maupun permasalahan kesehatan masing-masing individu. Saat ini ada banyak jenis fasilitas kesehatan yang dapat di akses oleh masyarakat baik itu milik pemerintah maupun swasta. Seperti Puskesmas, Rumah Sakit Umum Daerah, Rumah Sakit Swasta maupun klinik milik pribadi. Akan tetapi Rumah Sakit masih menjadi pilihan sebagain besar masyarakat untuk mendapatkan kebutuhan terkait dengan pelayanan kesehatan saat ini.

Oleh karena itu jumlah RS di Indonesia semakin meningkat, sejak tahun 2012 sampai dengan saat ini terdapat peningkatan sebesar rata-rata 5,2\%. Rumah Sakit di Indonesia terdiri dari rumah sakit publik dan rumah sakit privat dengan jumlah total 2,773. (http://sirs.yankes.kemkes.go.id/rsonline /report/ Diakses pada 13 Desember 2019)

Untuk itu rumah sakit harus berupaya untuk dapat memenuhi segala harapan tersebut dengan terus meningkatkan berbagai kualitas pelayanan yang ada saat ini. Saat ini masyaarakat dihadapkan pada banyak sekali pilihan pelayanan kesehatan, masyarakat pun menjadi semakin kritis dalam memilih layanan kesehatan. Untuk itu tentunya rumah sakit harus terus berupaya untuk dapat memenuhi ekspektasi masyarakat dengan meningkatkan mutu pelayanan dari waktu ke waktu secara berkesinambungnan dan berkelanjutan tanpa henti, sehingga mampu memberikan pelayanan prima bagi pelanggan nya yang telah mempercayakan kesehatannya kepada rumah sakit tertentu.

Mutu pelayanan kesehatan dapat diartikan dipenuhinya derajat kesehatan masyarakat ataupun individu akan asuhan kesehatan yang sesuai dengan standar profesi yang baik dengan memanfaatkann sumber daya secara wajar,eefisien,eefektif dalam keterbatasan kemampuan pemerintah dan masyarakat,sserta diselenggarakan secara aman dan memuaskan pelanggan sesuai dengan norma dan etika yang baik (Azrul Azwar (1999) dalam Bustami (2011)). Donabedian (1980) menyatakan terdapat tiga komponennpelayanan, terdiri dari masukann(inputtdisebut juga structuree),pproses, ddan hhasil (outcome). Masukan (input) yang merupakan sarana fisik, perlengkapan dan peralatan, organisasi dan manajemen keuangan, serta sumber daya manusia dan sumber daya (resources) lainnya di rumah sakit. Sementara pengkajian proses dapat dinilai dari pemberian pelayanan kesehatan sudah menjalankan segala jenis prosedur sesuai dengan regulasi yang berlaku. Hasil yang dicapai (Outcome) dapat dinilai dari perubahan perilaku pasien, seperti awalnya tidak mengetahui bagaimana prosedur pendaftaran pasien baru setelah diberikan proses pengetahuan pasien mengetahui setiap prosedur yang harus dilakukan sehingga mengurangi jumlah komplain yang diterima. Mutu pelayanan kesehatan ini dapat dinilai berdasarkan prespektif pasien / masyarakat ataupun pemberi layanan kesehatan.

Pasien/masyarakat sering menganggap bahwa dimensi efektivitas, aakses, hhubungan antar manusia,kkesinambungan, dan kenyamanan sebagai suatu dimensi mutu layanan kesehatan yang sangat pentingg. Untuk itu pemberi pelayanan kesehatan harus mampu kebutuhan dari masyarakat yang kan dilayani sehingga mampu medidik masyarakat dalam memilih cara yang efektif dalam mewujudkan layanan kesehatan. Sementara berdasarkan prespektif dari pemberi layanan kesehatan ditentukan dengan tersedianya fasilitas peralatan, adanya regulasi yang mengatur, serta kehandalan masing-masing profesi dalam memberikan pelayanan berdasarkan tekhnologi terkini hingga hasil dari pemberian layanan tersebut. (Imbalo S, 2007). Dari penilaian mutu pelayanan kesehatan ini diharapkan dapat meningkatkan kualitas dari pelayanan kesehatan tersebut.

Metode yang yang tepat untuk dijalankan dalam upaya peningkatan kulaitas salah satunya adalah dengan peningkatan kualitas secara sistem terpadu atau yang dikenal dengan Total 
Quality Management (TQM). TQM merupakan suatu pendekatan yang dilakukan dalam menjalankan usaha dengan mencoba untuk memaksimalkan daya saing organisasi melalui perbaikan terus menerus atas produk, jasa, manusia, proses dan lingkungannya. (Juharni, 2017). Sehingga kerjasama tim sangat dibuthkan dalam meningkatkan produktifitas sehingga menghasilkan outcome kepuasan pelanggan. Dengan kata lain, keterlibatan seluruh manajemen memiliki peranan kunci dalam menggerakkan seluruh karyawan untuk dapat menyalurkan segala kompetensi yang dimiliki demi mewujutkan tujuan mutu yaitu kepuasan pelanggan.

Tujuan Total Quality Management (TQM) ialah untuk memberikan produk untuk jasa berkualitas yang memenuhi kebutuhan dan kepuasan para konsumen berkelanjutan (sustainable satisfaction) yang pada gilirannya akan menimbulkan pembelian berkesinambungan sehingga dapat menimbulkan produktivitas produsen mencapai skala ekonomis dengan penurunan biaya produksii. Implikasi dari hal diatas ialah bahwa manajemen Totall QualitymManagementt(TQM) visi,mmisi,ddan kemampuan untuk mengembangkan pasar yang sudah ada maupun dapat mengantisipasi kebutuhan produk atau jasa yang akan datang,yyang saat ini mungkin belum ada sama sekali.kKreativitas dan kemampuan manajemen menciptakan pasar kebutuhan yang akan datang inilah yang akan menjamin kelangsungan hidup perusahaan sebagai pemimpin atau pioneer dalam pasar tersebutt (Juharni, 2017).

Beberapa Ahli mutu menjelaskan beberapa acara dalam mengimplementasikan TQM berdasarkan pendekatan yang berbeda. Menurut Bhat dan Cozzalino (1993), secara mendasar ada dua pendekatan yang berbeda. Pertama adalah pendekatan secara radikal yang dilakukan untuk memperbaiki metode bisnis dan kebiasaan yang tidak perlu dan menjadikan perusahaan berubah drastis. Pendekatan lainnya secara inkremental dilakukan oleh perusahaan yang membangun kualitas secara gradual dan bertahap. Sebagian besar implementasi TQM dewasa ini dilakukan secara inkremental karena pada hakekatnya merupakan pendekatan proses menuju perubahan budaya kualitas (Rohmad Kafidzin, 2016).

Total Quality Manajemen terdapat 10 komponen atau unsur yaitu focus pada pelanggan, obsesi terhadap kualitas, pendekatan ilmiah, komitmen jangka panjang, kerjasama tim (Team Work), perbaikan sistem secara berkesinambungan, pendidikan dan pelatihan, kebebasan yang terkendali, kesatuan tujuan, serta adanya keterlibatan dan pemberdayaan karyawan (Goetsch \& Davis, (1994) dalam Nasution 2015). Dari 10 komponen TQM diharapkan dapat memberikan kepuasan kepada pelanggan.

Kepuasan pelanggan ini merupakan bentuk evaluasi dari pelanggan dari hasi interaksi pembelian suatu produk atau jasa dibandingkan dengan harapan yang dia miliki. (Nasution, 2015, hlm 42). Pelanggan dibagi menjadi dua yakni pelanggan internal terdiri dari seluruh karyawan dalam sebuah organisasi dan pelanggan eksternal yang menikmati suatu produk atau jasa yang ditawarkan oleh suatu organisasi.

Sementara tolak ukur dari kepuasan pasien dapat dilihat dari 5 dimensi. Pertama realibilitas, Reabilitas merupakan kehandalan petugas dalam memberikan pelayanan yang dibutuhkan pelanggan dengan segera, akurat, memenuhi atau bahkan melebihi apa yang dibutuhkan sehingga mampu memuaskan pelanggan. Kedua daya tanggap, hal ini merupakan suatu keinginan petugas untuk dapat memberikan bantuan kepada seluruh pelanggan dengan penuh perhatian, secara cepat dan juga tepat. Ketiga jaminan, jaminan dapat diartikan petugas yang memiliki kompetensi, sikap dapat dipercaya, tidak menimbulkan bahaya dan risiko serta tidak memperlihatkan keraguan dalam sebuah tindakan. Keempat empati, merupakan kemampuan petugas untuk dapat menjalin hubungan komunikasi dengan memberikan perhatian terhadap pelanggan. Kelima bukti fisik atau bukti langsung, merupakan ketersediaan sarana prasarana, termasuk alat yang siap pakai serta penampilan 
petugas yang menyenangkan.

\section{METODE}

Pada penelitian ini menggunakan metode penelitian kualitatif, penelitian kualitatif yaitu penelitian yang mengharuskan peneliti mengumpulkan data untuk dapat dianalisis dan dinarasikan dengan menggunakannfocus group, wawancara mendalam,!dan juga observasi. Obyek penelitiankkualitatif adalah obyek yang alamiah, atau natural setting, sehingga metode penelitian ini sering disebut sebagai metode naturalistic. Obyek yang alamiah adalah obyek yang apa adanya, tidak dimanipulasi oleh peneliti sehingga kondisi saat peneliti memasuki obyek relatife tidak berubah. (Sugiyono, 2017).

Pada penelitian ini menggunakan pedekatan kualitatif dimana penelitian yang dilakukan bersifat deskriptif yaitu memberikan gambaran dan penjelasan yang tepat mengenai masalah yang dihadapi. Penelitian ini berpusat pada Rumah Sakit X yang berlokasi di J1. Industri Raya Nomor 100, Cikarang Utara, Kabupaten Bekasi. Dengan Waktu Penelitian selama 6 bulan bersamaan dengan pengolahan data yang diperoleh. Penelitian ini dimulai dari bulan Februari-Juli 2020. Fokus penelitian dilakukan pada penerapan metode Total Quality Management (TQM) dengan menganalisis bagaimana penerapan metode Total Quality Management (TQM) dapat meningkatkan mutu pelayanan secara optimal.

Pada penelitian kali ini data yang didapat melalui wawancara dan survey wawancara. Penentuan narasumber untuk wawancara menggunakan teknik snowball sampling. Beberapa narasumber ini dibedakan menjadi dua bagain yaitu key informan dan informan. Narasumber key informan ini terdiri dari Direktur RS X, Kepala Departemen Keperawatan dan Kepala Departemen MCM. Sementara untuk narasumber informan terdiri dari satu orang kepala bagian keperawatan, satu orang kepala bagian penunjang medis, satu orang kepala bagian Training and Performance, satu orang kepala bagian personalia, satu orang komite mutu dan 2 orang pasien. Dalam pemilihan informan ini dilakukan berdasarkan purposive sampling yang bisa mewakili dalam penerapan Total Quality Management di rumah sakit.

Teknik yang digunakan dalam pengumpulan data penelitian terdiri dari data primer dan data sekunder. Data primer merupakan data yang diperoleh atau yang diambil dari pengukuran secara langsung oleh peneliti sebagai sumber penelitian, pada penelitian ini data diperoleh melalui metode wawancara, metode observasi, dan metode focus group discussion. Pada metode wawancara, fokus pertanyaan yang diajukan oleh peneliti dalam penelitian ini berlandaskan kepada 10 unsur pokok pada penerapan metode Total Quality Management (TQM). Pertanyaan yang diberikan mulai dari peranan manajemen dalam peningkatan mutu pelayanan sampai ke peran karyawan dan kepuasan pasien. Adapun waktu pelaksanaannya data primer dilakukan pada rentang tanggal 10 juli sampai 31 juli, dengan rincian wawancara dilakukan pada 14 juli -24 juli, FGD dilakukan pada tanggal 24 juli bertempat di auditorium lantai 4 RS X dengan peserta diskusi terdiri dari Key Informan da Informan, untuk kegiatan observasi dilakukan dari 10 Juli sampai 31 Juli. Sementara untuk data sekunder diperoleh dari studi kepustakaan dan studi dokumentasi.

Dari data yang telah didapat selanjutnya dilakukan analisa data berbasis analisa isi (analysis content). Pada analisa data ini dilakukan dengan cara menelaah seluruh data hasil wawacara dan telaah dokumen, mereduksi data dengan cara membuat rangkuman inti, menyajikan Data/ Data Display berupa Flow Chart, mengimpretasikan data yang telah direduksi dan disajikan dalam bentuk narasi. Selanjutnya data data tersebut diperiksa keabsahan datanya. Pemeriksaan kebsahan data dilakukan untuk mengurangi data yang bias dan terlau subjektif dengan menggunakan metode triangulasi. Metode ini terdiri dari tringulasi sumber, tringulasi metode, dan tringulasi data. Tringulasi sumber merupakan pemeriksaan data/informasi dari informasi yang berasal dari minimal tiga informan terdiri dari kelompok 
yang berbeda seperti top manager, middle manager, lower manager dan group leader kemudian dilakukan coss check data dengan fakta dari sumber lain sehingga hasilnya daapat saling memperkuat antara satu dengan lainnya. Untuk tringulasi metode merupakan pemeriksaan data dengan cara mengumpulkan data tidak hanya melalui wawancara mendalam, tetapi juga melalui observasi dan telaah dokumen. Sementara untuk tringulasi data merupakan metode dengan cara melakukan analisis data, membuat kesimpulan dan meminta feedback dari informan agar data/ informasi yang didapat lebih absah.

\section{HASIL DAN PEMBAHASAN}

\section{Gambaran Umum RS X}

Rumah Sakit X pertama kali melayani pasien pada tanggal 12 Mei 2010. Pembukaan rumah sakit dilandasi adanya kebutuhan akan pelayanan kesehatan bertaraf internasional di wilayah Keluarga Cikarang dan sekitarnya. Rumah Sakit X merupakan rumah sakit swasta tipe B dengan jumlah kapasitas 142 tempat tidur. Rumah Sakit X memiliki visi yaitu "Kami berkeinginan kuat menjadi penyedia pelayanan kesehatan terdepan yang berfokus pada pelanggan" (We desire to be the peoplecentered and leading edge healthcare) dan misinya yaitu "Kami berkomitmen untuk mengoptimalkan kualitas hidup orang banyak dengan pelayanan yang penuh kasih sayang, terpercaya, dan berfokus pada pelanggan" ( $W e$ are commited to optimize million's quality of life by providing Compassionate-Trusted-Patient Oriented Care). Sementara untuk nilai-nilai dasar dari RS X adalah GREAT (carin $G$, Respect, Excellent, innovAtive, dan Teamwork). Sedangkan ciri khas dari RS X adalah 3L yang terdiri dari Life, Love, Laughter (Kehidupan, Cinta dan Kegembiraan).

\section{Sistem Kepemimpinan RS $\mathrm{X}$}

Pemilik Rumah Sakit X adalah PT

Proteindo Karya Sehat yang merupakan pemegang kekuasaan tertinggi yang dipilih melalui mekanisme rapat umum pemegang saham (RUPS) PT.Proteindo Karya Sehat yang mengangkat dan memberhentikan Direktur PT Proteindo Karya Sehat sebagai wakil pemilik untuk menjalankan tugas, kewenangan, dan tanggungjawab badan pengurus. Direktur PT bertugas menentukan dan menyusun arah kebijakan dan strategi pengembangan RS, mengawasi dan memberikan nasehat serta bimbingan kepada Direktur RS dan Staf Manajemen dalam pengelolaan rumah sakit yang dilakukan baik di dalam maupun di luar rapat untuk mewujudkan Rumah Sakit sesuai dengan filosofi yang dianut.

Sedangkan untuk calon Kepala Departmen yang telah memenuhi persyaratan diusulkan oleh Direktur RS kepada Badan Pengurus. Calon kepala departemen yang telah disetujui oleh Badan Pengurus diangkat dan ditetapkan menjadi Manajer atau Asisten Manajer oleh Direktur RS X. Kemudian Kepala Bagian dipilih oleh Kepala Departemen sebagai atasan langsung dan kemudian disetujui oleh Direktur Rumah Sakit.

Pada penelitian ini, pemilihan informan berdasarkan pemahaman informan yang dianggap memahami terkait penelitian yang dilakukan. Sehingga dalam pemilihan informan ini berasal dari berbagai kalangan, dengan distribusi informan berdasarkan jabatan atau pekerjaan dapat dilihat pada tabel 1 .

Hasil Tabel 1 menunjukan bahwa informan dalam penelitian ini berasal dari berbagai kalangan, informan dengan presentasi terbanyak berasal dari kepala bagian yakni sebesar 45\%, sementara untuk kalangan kepala departemen dan staf sama di angka $22 \%$ dan direktur 11\%. Hal ini menunjukkan bahwa dalam penerapan metode Total Quality Management peranan antara manaejemen

Tabel 1. Distribusi Informan Berdasarkan Jabatan / Pekerjaan

\begin{tabular}{|c|c|c|c|}
\hline $\mathrm{No}$ & Jabatan & Jumlah & Presentase \\
\hline 1 & Direktur & 1 & $11 \%$ \\
\hline 2 & $\begin{array}{l}\text { Kepala } \\
\text { Departemen }\end{array}$ & 2 & $22 \%$ \\
\hline 3 & Kepala Bagian & 4 & $45 \%$ \\
\hline 4 & $\begin{array}{l}\text { Staf Pelaksana } \\
\text { Jumlah }\end{array}$ & $\begin{array}{l}2 \\
8\end{array}$ & $\begin{array}{l}22 \% \\
100 \%\end{array}$ \\
\hline
\end{tabular}

(Sumber data: Data Karyawan RS X) 
Tabel 2. Karakteristik Informan Berdasarkan Pendidikan

\begin{tabular}{llll}
\hline No & Pendidikan & Jumlah & Presentase \\
\hline 1 & S2 & 1 & $11 \%$ \\
2 & S1 & 5 & $67 \%$ \\
3 & DIII & 2 & $22 \%$ \\
& Jumlah & 8 & $100 \%$ \\
\hline
\end{tabular}

(Sumber Data : Data Karyawan RS X)

rumah sakit sebagai pembuat kebijakan dengan pelaksana lapangan sama besarnya dalam upaya peningkatan mutu pelayanan. Sementara karakteristik informan kami bagi berdasarkan pendidikan dapat dilihat pada tabel 2 .

Berdasarkan Tabel 2. diatas, maka latar belakang pendidikan informan dengan presentasi sebanyak $67 \%$ lulusan $\mathrm{S} 1$ dan sebanyak $22 \%$ lulusan D III dan $11 \%$ lulusan S2. Hal ini bertujuan bahwa dalam menggali data terkait penerapan metode Total Quality Management dalam upaya peningkatan mutu melalui wawancara mendalam da, FGD diperoleh dari narasumber yang memang ahli dibidangnya.

\section{Analisa Berdasarkan Pengumpulan Data dan} Wawancara Mendalam

Dalam upaya peningkatan mutu pelayanan dapat dilakukan dengan menerapkan beberapa metode salah satunya adalah metode Total Quality Management yang dalam penelitian ini masuk kedalam komponen Proses. Dalam pelaksanaannya upaya peningkatan mutu menerapkan beberapa komponen yang terdiri dari komponen input, proses dan kemudian komponen output.

\section{Komponen Input}

Salah satu komponen input adalah sumber daya manusianya, dalam hal ini petugas yang terdiri dari medis/paramedis, dan non medis yang dimiliki oleh rumah sakit. Dalam undang-undang No. 44 Tahun 2009 tentang Rumah Sakit pasal 12 menjelaskan persyaratan suatu Rumah Sakit adalah memiliki tenaga tetap yang terdri atas tenaga medis, tenaga keperawatan, tenaga kefarmasian, tenaga manajemen Rumah Sakit dan tenaga Kesehatan yang mana jumlah dan jenis sumber daya manusia harus disesuaikan pula dengan jenis dan klasifikasi rumah sakit.

Dari informasi yang didapat setelah melakukan wawancara dan data RS, didapatkan bahwa Rumah sakit Mitra keluarga dalam upaya peningkatan kualitas mutu salah satunya dengan menyediakan sumber daya manusia sesuai dengan kebutuh pelayanan dan sesuai dengan kualifikasi yang dibutuhkan. Rumah Sakit terus berupaya untuk memenuhi sumber daya manusia yang dibutuhkan sesuai dengan jenis pelayan yang tersedia dan meningkatkan kompetensi sumber daya manusia dengan pendidikan dan pelatihan.

Komponen input selanjutnya adalah biaya, di Rumah Sakit $\mathrm{X}$ dalam memastikan pelayanan yang maksimal membuat perencanaan biaya setiap tahunnya yang dikenal dengan istilah budgetting yang kemudian perencaan anggaran biaya tersebut dituangkan kedalam bentuk Rencana Kerja Anggaran dan disahkan oleh diektur PT setiap tahunnya. Dalam penyusunan rencana kerja anggaran, direktur meminta rincian perencanaan anggaran dari masing-masing unit yang disetujui oleh kepala departemen yang kemudian dijadikan anggaran rumah sakit. Menurut wawancara dan observasi dari telaah dokumen didapatkan informasi dalam pelaksanaan pelayanannya Rumah sakit X harus mengacu kepada RKA yang telah terorganisir dari awal tahun diperuntukkan untuk apa saja. Hal ini sejalan dengan yang telah dijabarkan dalam Undangundang Nomor 44 Tahun 2009 pasal 8 ayat 1 tentang Rumah sakit bahwa Rumah sakit harus membuat kajian kebutuhan dalam menyelenggarakan operasional Rumah Sakit diantaranya kajia terhadap kebutuhan dana.

Komponen input ketiga adalah material, berdasarkan observasi dan dilakukan telaah data dari profil Rumah Sakit, dalam memenuhi harapan dan keinginan pelanggannya $X$ menyediakan pelayanan kesehatan yang juga mengacu kepada Peraturan Menteri Kesehatan nomor 3 tahun 2020 tentang klasifikasi dan perizinan Rumah Sakit, yakni Pelayanan Gawat Darurat, Pelayanan Poli Spesialis Rawat Jalan, Pelayanan Rawat Inap. Selain Pelayanan tersebut, berdasarkan observasi yang dilakukan 
oleh peneliti kepada komite-komite yang ada di Rumah Sakit upaya yang dilakukan manajemen dalam peningkatan kualitas mutu pelayanan adalah dengan memastikan tenaga profesi yang bekerja sudah memiiki sertifikasi untuk non medis dan Surat Izin Praktek (SIP) dan Surat Tanda Registrasi (STR) untuk tenaga profesi. Hal ini juga merupakan bentuk upaya dalam menjalankan kewajiban Rumah Sakit yang dijelaskan dalam Undang-Undang nomor 36 tahun 2014 tentang Tenaga Kesehatan BAB VI pasal 44 ayat 1 dan pasal 46 ayat 1 menjelaskan bahwa setiap tenaga kesehatan yang menjalankan praktik diwajibkan untuk memilik STR dan setiap tenaga kesehatan yang melakukan praktik dibidang pelayanan kesehatan diwajibkan untuk memiliki SIP. Dalam hal ini Rumah Sakit Mitra Cikarang telah menjalankannya dan memastikan data perizinan tersebut masih berlaku.

Komponen input keempat adalah metode, Berdasarkan hasil observasi yang dilakukan di bagian Quality Management Representative (QMR) atau bagian mutu Rumah Sakit didapatkan bahwa dalam memberikan pelayanan Rumah Sakit Mitra dilengkapi dengan Regulasi yang mendasari dari seluruh kegiatan yang dilakukan, regulasi terdiri dari kebijakan direktur sebagai regulasi tertinggi, pedoman pelayanan, pedoman pengorganisasian, panduan kerja, Standar Prosedur Operasional (SPO) kemudian didokumentasikan kedalam formulir. Dalam penyusunan regulasi di Rumah sakit Mitra Keluara Cikarang mengacu kepada peraturan yang dikeluarkan oleh pemerintahan yang masih berlaku yang direkap didalam lembar kerja undang-undang. Hal ini sejalan dengan yang dijelaskan dalam Peraturan Menteri Kesehatan nomor 4 tahun 2018 tentang kewajiban Rumah Sakit dan Kewajiba pasien BAB II pasal 11 yaitu bahwa Rumah Sakit mempunyai kewajiban untuk dapat membuat menjalankan dan menjaga serta mengevaluasi standar mutu pelayanan yang digunakn sebagai acuan dalam memberikan layanan kepada pasien.

Sementara untuk komponen input kelima adalah mesin, berdasarkan observasi dan melihat data fasilitas yang tersedia di sekretariat Rumah sakit $\mathrm{X}$ dari segi kelengkapan peralatan medis dan juga tekhnologi sudah sangat mempuni, update peralatan dan tekhnologi masih terus dilakukan sesuai dengan kebutuhan pengembangan pelayanan maupun yang dipersyaratkan dalam regulasi pemerintah, yang saat ini mengacu kepada Peraturan Menteri Kesehatan Nomor 3 tahun 2020 tentang klasifikasi dan perizinan Rumah Sakit. Dukungan manajemen dalam pemenuhan kebutuham kelengkapan peralatan demi berjalannya operasional Rumah Sakit X sudah sangat baik mengikuti perkembangan tekhnologi dan regulasi pemerintah yang berlaku saat ini.

2. Komponen Proses

Pada bagian komponen proses ini terdapat 10 komponen yang kami analisis. Komponen pertama adalah focus kepada pelanggan, gambaran apakah rumah sakit sudah meperhatikan pelayanan yang fokus pada pelanggan dapat dilihat dari kepuasan pasien itu sendiri yang artinya rumah sakit harus memahami kompnen-komponen yang berkaitan dengan kepuasan pasien. Secara sederhana kepuasan pasien dapat diartikan suatu keadaan dimana kebutuhan, keinginan dan harapan pelanggan dapat terpenuhi melalui pelayanan yang diterima. Dari hasil telaah dokumentasi yang peneliti lakukan didapakan informasi bahwa dalam memberikan pelayanan yang berfokus kepada pelanggan/ pasien Rumah sakit $\mathrm{X}$ selalu berpegang teguh pada misi rumah sakit yakni "Kami berkomitmen untuk mengoptimalkan kualitas hidup orang banyak dengan pelayanan yang penuh kasih sayang, terpercaya dan fokus pada pelanggan". Sementara berdasarkan observasi dan telaah dokumen regulasi terlihat pada kebijakan Peningkatan Mutu dan Keselamatan Pasien serta melibatkan karyawan untuk berhubungan langsung dengan pasien serta memberdayakan karyawan untuk mereka dapat mengambil langkah dalam upaya memuaskan pasien dengan langsung berinteraksi dengan para pasien adalah hal yang sangat penting untuk mewujutkan pelayanan yang berfokus kepada pelanggan yang dalam hal 
ini dirumah sakit adalah pasien.

Komponen kedua adalah obsesi terhadap kualitas, pada komponen ini terlihat dari kualitas pekerjaan masing-masing karyawan yang ditempatkan di unit tertentu. Dari observasi dan telaah dokumen menjelaskan penilaian kinerja di Rumah sakit X dilakukan untuk seluruh karyawan yang mana dalam penilaian kinerja memiliki indikator yang berbeda-beda disetiap unit nya tergantung pada jenis pelayanan yang dihasilkan unit tersebut. Hasil dari penilaian kinerja ini yang kemudian menjadi menjadi tolak ukur dalam pemberian reward kepada masing-masing staf berupa kenaikan gaji tahun berikutnya bahkan sampai dengan promosi. Sehingga dengan adanya reward, setiap orang menjadi terobsesi dalam mencapai suatu kulitas pekerjaan dengan adanya dukungan top management. Semakin banyak karyawan memiliki obsesi terhadap suatu kualitas dalam pekerjaan maka mereka akan memberikan pelayanan yang memuaskan baik bagi pelanggan internal maupun eksternal, secara otomatis tentunya kinerja rumah sakit akan meningkat.

Komponen ketiga adalah pendekatan ilmiah, dikarenakan ilmu pengetahuan terus berkembang, maka rumah sakit wajib menyediakan referensi sesuai perkembangan ilmu pengetahuan dan teknologi untuk mendukung pelaksanaan program rumah sakit dalam upaya peningkatan mutu dan 80 keselamatan pasien. Pada hal ini RS X telah menyediakan ruangan perpustakaan yang mana didalamnya terdapat buku-buku sebagai referensi pendekatan ilmiah dalam pembuatan suatu regulasi ataupun pengambilan keputusan dalam satu permasalahan. Akan tetapi belum dijelaskan secara tertulis uraian tugas, tanggungjawab dan wewenangnya sebagai penanggungjawab perpustakaan. Perpustakaan berada dilantai 4 gedung Rumah sakit $\mathrm{X}$, namun fasilitas ini belum digunakan oleh karyawan secara optimal, terlihat selama peneliti melakukan observasi tidak tampak ada tampak karyawan yang datang mengunjungi ruangan perpustakaan tersebut. Selain fasilitas ruangan perpustakaan dalam memenuhi referensi pendekatan ilmiah sebagai dasar segala aktifitas pelayanan Rumah Sakit $X$ juga menyediakan fasilitas wifii yang dapat di akses oleh seluruh karyawan dilingkungan Rumah sakit, serta memaksimalkan fungsi organisasi komite masing-masing profesi yang ada di Rumah sakit untuk membantu memastikan pembaharuan sumber referensi ilmiah yang dipakai.

Komponen keempat adalah komitmen jangka panjang, Seluruh karyawan yang bekerja harusalah mempunyai komitmen yang sama dengan perusahaan tempat dia bekerja dalam memcapai visi misi dan tujuan perusahaan. Dari hasil observasi penulis dengan bagian TNP untuk memastikan seluruh karyawan mengetahui visi dan misi Rumah sakit $\mathrm{X}$ manajemen melalui unit TNP (Training and Performance) menjadwalkan pelaksanaan pelatihan internal untuk menjabarkan visi misi dan juga penerapan core value dilingkungan Rumah Sakit X. Target peserta dari pelatihan ini adalah seluruh karyawan yang bekerja di Rumah sakit, selain diadakan pelatihan internal setiap bulan ada pula orientasi untuk karyawan baru yang salah satu materinya adalah mengenai profil rumah sakit yang didalamnya terdapat materi visi misi dan core value Rumah Sakit.

Komponen kelima adalah kerjasama tim, menjalin kerjasama tim ini untuk mencapai tujuan bersama. Kerjasama tim yang terjalin di Rumah Sakit $\mathrm{X}$ terdiri dari kerjasama antar karyawan Rumah sakit, kerjasama antar supplier, dan kerjasama dengan badan pemerintah. Kerjasama tim yang terjalin dapat dilihar dari pemecahan masalah yang terjadi di unit, yang mana jika 90 terjadi kesalahan dalam sebuah unit maka seluruh karyawan di unit tersebut akan saling membantu. Sementara upaya yang dilakukan oleh manajemen untuk mempererat kerjasama tim di rumah sakit salah satunya dengan melakukan rotasi karyawan yang tentunya sesuai dengan kompetensi mereka ditempatkan, pelaksanaan rotasi dikelola oleh bagian personalia atau HRD yang berkoordinasi dengan Ka.Bag dan Ka.Dept masing-masing departemen. Rumah Sakit X 
sudah menjalin kerjasama yang baik dengan supplier atau pemasok, dilihat dari terjalinnya kerjamasa yang jelas dengan adanya Perjanjian Kerja Sama yang disepakati oleh kedua belah pihak. Untuk menjamin mutu dari supplier pun Rumah Sakit X melakukan evaluasi berkala untuk menentukan perpanjangan perjanjian kerjasama kedepannya. Dari hasil wawancara didapatkan informasi kerjasama dengan lembaga pemerintah juga sudah berjalan dengan baik di Rumah Sakit X, lembaga pemerintah tersebut antara lain Dinas Kesehatan dan Juga Puskesmes wilayah kerja terkait. Untuk keikutsertaan Rumah Sakit secaara rutin dilakukan program Promosi Kesehatan Rumah Sakit (PKRS) dengan berbagai kegiatan diantaranta penyuluhan, mengikuti kegiatan POSYANDU dan lain sebagainya.

Komponen keenam adalah perbaikan sistem secara berkesinambungan. Berdasarkan observasi yang peneliti lakukan didapatkan informasi bahwa Perbaikan sistem secara berkesinambungan terus diupayakan oleh Rumah Sakit X yakni diantaranya ada beberapa program rutin yang selalu dilakukan adalah kegiatan continuous improvement (CONIM) yakni suatu usaha yang dilakukan secara terus menerus, mengembangkan dan memperbaiki layanan ataupun proses dengan mengidentifikasi peluang perbaikan yang dapat dilakukan untuk meningkatkan aktivitas dan mengurangi segala bentuk pemborosan. Selain CONIM yang diadakan dalam lingkup yang lebih luas upaya perbaikannya berkesnmabungan juga dilakukan dengan meminta sumbang saran/ Sugestion Sytem dari masing-masing karyawan, Rumah Sakit memberikan target kepada masing-masing karyawan untuk dapat memberikan sumbang saran minimal 2 dalam setahun. Upaya Rumah Sakit $X$ dalam meningkatkan kualitas pelayanan dengan menerapkan unsur perbaikan berkesinambungan sudah dilakukan dengan menjalan program CONIM dan SS, yang mana karyawan sudah terlinat secara aktif. Akan tetapi dilihat dari perbaikan sistem IT tidak banyak keterlibatan karyawan dikarenakan sistem sudah digarap oleh Tim IT dari corporate
Mitra Keluarga Group.

Komponen ketujuh adalah pendidikan dan pelatihan. Seteleh disediakannya Man berupa sumber daya manusia maka langkah berikutnya yang perlu dilakukan oleh Rumah sakit adalah mengembangkan sikap, skill serta kemampuan sumber daya manusia yang tersedia dengan cara memberikan pendidikan dan pelatihan sehingga mampu meningkatkan loyalitas dan kinerja karyawan. Dalam hal ini Rumah Sakit $\mathrm{X}$ mempunyai komitmen yang tinggi, terlihat dari hasil wawancara, observasi dan telaah dokumen, terlihat dari Rumah sakit mempunyai regulasi jelas yang mengatur tentang pelaksanaan pendidikan dan pelatihan, menyediakan alokasi dana setiap tahun untuk program pendidikan dan pelatihan, menjalin kerjasama dengan intitusi-institusi pendidikan untuk memberikan pendidikan lanjuan bagi karyawan, dan dijalankan program pelatihan rutin setiap bulan nya bagi seluruh karyawan yang bekerja.

Komponen kedepalan adalah kebebasan terkendali, Sebuah organisasi dianggap perlu melakukan pengendalian terhadap segala proses kerja dan metode yang digunakan selama proses berlangsung dengan tujuan dapat 112 mengurangi pernyimpangan yang mungkin terjadi, termasuk didalamnya mengendalikan kebebasan berpendapat, dalam arti kata seluruh karyawan diberikan kebebasan yang terkendali dalam mengutarakan segala masukan-masukan yang diberikan. Penerapan unsur kebebasan terkendail di Rumah Sakit X sudah dijalankan dengan didiskusikan terlebih dahulu kepada atasan langsung.

Komponen kesembian adalah kesatuan tujuan. Direktur sebagai pimpinan tertinggi di Rumah sakit bertanggungjawab untuk memastikan misi tersebut dapat diketahui, dipahami dan di implementasikan oleh seluruh karyawan dalam memberikan pelayanan yang bermutu setiap harinya. Untuk mewujudkan hal tersebut melalui unit TNP (Training and Performance) mejadwalkan pelaksanaan pelatihan internal untuk menjabarkan visi misi dan juga penerapan core value dilingkungan Rumah Sakit X. Pada prinsipnya manajemen 
perusahaan memastikan karyawan memiliki pemahan yang jelas terhadap tujuan dari organisasi sehingga menghasilkan manajemen dan karyawan bersama-samaturut aktif dalam menjalankan dan mencapai tujuan organisasi. Berlatar belakang dari hal tersebut sudah seharusnya Rumah Sakit melibatkan karyawan secara aktif dalam merumuskan perencanaan tujuan yang ingin dicapai oleh Rumah Sakit, baik saat penyususan rencana jangka panjang (RENSTRA) dan kemudian melakukan sosialisasi terkait tujuan yang akan dicapai agar karyawan pun merasa bertanggungjawab dalam mencapai tujuan tersebut sehingga karyawan dan manajemen Rumah Sakit memiliki kesatuan tujuan yang sama.

Komponen kesepuluh adalah Adanya keterlibatan dan pemberdayaan karyawan. Rumah sakit $\mathrm{X}$ dalam melibatkan dan memberdayakan karyawan melakukan beberapa langkah dasar yakni dengan adanya regulasi terkait dengan agenda pertemuan rutin atau yang disbeut dengan rapat, dengan berbagai jenis rapat sesuai dengan tingkatn organisasi. Rapat yang efektif menghasilkan keputusan yang baik dan membangun rasa kebersamaan. Rapat juga sebagai bentuk proses bentuk pertemuan untuk 117 evaluasi dan pemecahan masalah internal terkait yang terjadi dan pemecahan masalah internal yang terjadi dilingkungan rumah sakit.

\section{Output}

Output dari penelitian ini adalah kepuasan pasien dari diterapkannya Total Quality Management (TQM) di Rumah Sakit $\mathrm{X}$. Informasi komponen output didapatkan oleh peneliti dari hasil wawncara dengan beberapa pasien dan juga melakukan observasi. Peneliti memberi kode untuk pasien yang diwawancara dengan P1 yang berarti pasien 1 dan P2 sebagain pasien kedua yang diwawancarai. Dalam penelitian ini yang menjadi tolak ukur kualitas pelayanan adalah fasilitas / bukti fisik, kehandalan, daya tanggap, jaminan, empati. Dari hasil wawancara dari sejumlah pasien yang dilakukan, maka penulis menyimpulkan bahwa di Rumah Sakit X telah memberikan pelayanan yang baik kepada pasien, meskipun memang masih ada beberapa hal yang perlu diperbaiki, namun jika Rumah sakit $\mathrm{X}$ terus meningkatkan pelayanannya maka pasien akan selalu merasa puas dengan pelayanan yang diberikan. Setelah melakukan analisa dan wawancara dilakukanlah FGD (Focus Group Discussion)

\section{Focus Group Discussion (FGD)}

FGD dihadari oleh seluruh informan yang terdiri dari informan kunci dan informan. Dalam pelaksanaan FGD peneliti dibantu oleh seorang fasilitator yang membantu dalam mendokumentasikan berjalannya FGD. Forum dipimpin oleh peneliti dengan topik yang diangakat terkait dengan bagaimana penerapan 10 unsur pokok Total Quality Management (TQM) di Rumah Sakit X. Peneliti mengarahkan jalannya diskusi lebih kepada permasalahan atau kendala yang dihadapi dalam penerapan 10 unsur pokok TQM. Segala pelayanan yang diberikan dengan menerapkan TQM sangat berpengaruh terhadap kualitas mutu pelayanan. TQM sangat mempengaruhi peningkatan mutu pelayanan kepada pasien Rumah Sakit $\mathrm{X}$ melalui dimensi mutu pelayanan yang meliputi kehandalan, daya tanggap, jaminan, empati dan bukti fisik/fasilitas yang telah diterapkan. Sejumlah pasien memberikan tanggapan positif terhadap pelayanan yang diberikan, hal ini tidak terlepas dari penerapan TQM yang senantiasa berfokus kepada kepuasan pasien.

\section{PENUTUP}

Dari penelitian yang telah dilakukan didapatkan kesimpulan pertama adalah dukungan manajemen dalam upaya peningkatan kualitas pelayanan telah dilakukan secara penuh. Selanjutnya, dari 10 unsur penerapan Total Quality Management (TQM) didapatkan bahwa unsur fokus pada pelanggan, unsur obsesi terhadap kualitas, unsur pendekatan ilmiah, unsur kerjasama tim, unsur perbaikan sistem berkesinambungan, unsur pendidikan dan pelatihan, unsur kebebasan terkendali, unsur kesatuan tujuan, serta adanya keterlibatan pemberdayaan karyawan sudah dijalankan oleh Rumah sakit. Akan tetapi unsur 
komitmen jangka panjang dalam hal sosialisasi rencana strategis belum dilakukan secara optimal sehingga belum seluruh karyawan mengetahui komtmen jangka panjang yang ingin dicapai oleh Rumah Sakit. Selanjutnya kesimpulan ketiga adalah Pelayanan yang diberikan oleh Rumah sakit $\mathrm{X}$ sudah cukup baik. Kesimpulan keempat yaitu Dalam meningkatkan mutu pelayanannya kepada pasien, Rumah sakit $\mathrm{X}$ berusaha semaksimal mungkin dalam menerapkan TQM. Terakhir kesimpulannya adalah penerapan sepuluh karakteristik TQM menjadi indikasi pelayanan yang baik yang diberikan oleh Rumah sakit $\mathrm{X}$ dengan senantiasa memberikan pelayanan sesuai dengan harapan dan keinginan pasien.

\section{DAFTAR PUSTAKA}

Ahmad, Muchtar. 2011. Analisis Manajemen Mutu Terpadu (TQM) dalam Pelayanan Rumah Sakit.

Artista,Winda P. 2016. Pengaruh Total Quality Management, Sistem Pengukuran Kinerja dan Sistem Penghargaan Terhadap Kinerja Manajerial. Fakultas Ekonomi, Universitas Sam Ratulangi.

Bustami. 2011. Penjaminan Mutu Pelayanan Kesehatan \& Akseptabilitasnya. Jakarta:Erlangga

Bhat, V., J. Cozzolino. 1993. Total Quality: An Effective Management Tool, www.casact.org, pp.101-123.

Dale, B.G. 2003. Developing, Introducing and Sustaining $T Q M$, www.blackwellpublishing.com, p. 1-33, Mei 2020.

A1-Shdaifat, Emad A. 2015. Implementation of Total Quality Management in Hospitlas.Medical Sciences, Taibah University..

Engel, J,F, dkk. 1993. Custumer Behavior. Edition Erlando, Florida: The Dryden Press.

Otieno, Emmanuel Awuor. Total Quality Management Practices in Selected Private Hospitals in Nairobi, Kenya. Mangement University, Africa.

Sari, F. 2018. Metode Dalam Pengambilan Keputusan. Yogyakarta:CV Budi Utama

Hasmi, K. 2004. Introduction and Implementation of Total Quality Management (TQM), www.isisigma.com, Mei 2020.

Hidayah, N. 2015. Model Manajemen Mutu Terpadu Pelayanan Kesehatan Untuk Pengembangan Rumah Sakit Umum Daerah Kota Makassar. Universitas Alaudin, Makassar.
Husna. 2014. Penerapan Manajemen Terpadu dan Dampaknya di SD Budi Mulia Dua Sedayu Bantul. Bantul.

Irwanto. 2006. Focussed Group Discussion (FGD). Jakarta: Yayasan Pustaka Obor Indonesia

Jesihana, M. 2017. Kajian Implementasi Mutu dengan Pedekatan Integrasi Six Sigma dan TQM Melalui Penilaian Malcolm Baldridge di Rumah Sakit Cahritas Palembang. Program Pasca Sarjana Kajian Administrasi Rumash Sakit Indonesia. Fakultas Kesehatan Masyarakat Universitas Indonesia.

Juharni. 2017. Manajemen Mutu Terpadu. Makassar: CV Sah Media

Manurun, J, M. 2017. Implementasi Mutu dengan Pendekatan Integrasi Six Sigma dan TQM melalui penilaian Malcolm Baldridge di Rumah Sakit Charitas Palembang. Fakultas Kesehatan Masyarakat, Universitas Indonesia.

Kondoj., Nangio., Gerungai. 2017. Analisis Penerapan Total Quality Management dan Sistem Penlaian Kinerja pada PT SULUTGO. Universitas Sam Ratulangi, Manado.

Kafidzin, Rohmad. 2016. Analisis Implemantasi Total Quality Management (TQM) Pelayanan Rawat Inap di RS Kumalasiw Mijen Kudus. Universitas Diponegoro.

Kalesaran, J, E. 2011. Pelayanan Prima (Service Excellent) di Rumah Sakit.

Laksono. 2008. Analisis Kepuasan dan Hubunga dengan Loyalitas Pasien di Rawat Inap di Ruma Sakit Dedi Jaya Kabupaten Brebes. Tesis. Program Studi Magister Ilmu Kesehatan Masyarakat. Universitas Dipoegoror.

Adhiputra, M, W. 2018. Analisis Penerapan TQM Terhadap Kinerja Manajerial Pada Rumah Sakit Umum di Denpasar. STMIK STIKOM, Bali.

Pereira, M, G., Cister, A, M. 2016. Total Quality Management in the Hospital Area and its Contribution to Patient Safety. US

Munizu, M. 2010. Praktik Total Quality Management (TQM) dan Pengaruhnya Terhadap Kinerja Karyawan. Jural Manajemen dan Kewirausahaan. Vol 12. 2010

Nasution, N. 2015. Manjemen Mutu Terpadu. Edisi Ketiga, Bogor: Ghalia Indonesia.

Nurdiani, N. 2014. Teknik Sampling Snowball Dalam Penelitian Lapangan. Universitas BINUS, Jakarta..

Novrianto, dkk. 2014. Analisis penerapan Total Quality Management (TQM) industry pertahanan. Fakultas Teknik, Malang. 
Simamora, Henry. 2002. Manajemen Sumber Daya Manusia. Edisi Kedua, BP. STIE YKPN, Yogyakarta.

Sugiyati, S., Alriani, I, M. 2013. Pengaruh Total Quality Management dan Motivasi Kerja Terhadap Kinerja Perawat. STIE Dharma Putra, Semarang.

Thabrany, Hasbullah. Reformasi Pelayanan Kesehatan Harus Lebih Baik Memihak kepada Masyarakat. Diakses melalui https//www.google.cum/url?sat\&rct=j\&q=\& esrc $=$ s \& source $=$ web\&cd $=3 \&$ cad $=$ rja $\&$ uact $=8$ \&ved=0ahUKEwjdgO3vjdpPPAhUaTY8KH SeAUgQFggvMAI\&url=http $\% 3 \% 2 \mathrm{~A} \% 2 \mathrm{~F} \% 2$ Fstaff.ui.ac.id $\% 2$ Fsystem $\% 2$ Files $\% 2$ Fusers $\% 2$ Fhasbulah\%2Fmaterial\%2Fsistempendanaank esehatanptopublik.pdf\&usg=AFQjCNF91QX q6mKTljYjSTuLAYGEIRdAMA. Diuduh tanggal 03 Mei 2020

Tjiptono. 2016. Total Quality Management. Cetakan Kedua, Yogyakarta: PT Gramedia Pustaka Utama, 2004 Yunida, Margita, Pegaru Citra Rumah Sakit dan Kaualtas Pelayanan terhadap oyalitas Pelanggan melalui Kepuasan Pelangga Jurusan Manajemen Fakultas Ekonomi. Uiversitas Negeri Yogyakarta:Skrpsi.

Panesar, S. 2017. At A Glance Keselamatan Pasien dan Peningkatan Mutu Pelayanan Kesehatan. Medan: Erlangga.

Patel,G, B.E-Biomedical Engg, 2015. Total Quality Management in Healthcare. Manipal University, India.
Pohan, I, S. 2007. Jaminan Mutu Layanan Kesehatan. Jakarta: Buku Kedokteran EGC.

Ramseook, P, Munhurrun., Vedmani Munhurun., Arkrasunsingh, 2011. Total Quality Management Adstion in a Public Hospital: Evidence From Mauritius.University of Technology, Mauritius.

Masinambow, R, G., Karutu, M, M. 2019. Analisis Penerapam Total Quality Manegement di Rumah Sakit Siloam GMIM Sonder. Fakultas Ekonomi dan Bisnis, Unversitas Sam Ratulangi.

Rohmad, K. 2016. Analisis Implemantasi Total Quality Management (TQM) Pelayanan Rawat Inap di $R S$ Kumalasiwi Mijen Kudus.Universitas Diponegoro.

Sari. 2017. Implementasi Manejemen Mutu Terpadu di PAUD PGTK IT Harapan Mulia. Universitas Negeri Yogyakarta.

Sugiyono. 2008. Metode Penelitian Bisnis. Alfabeta: Bandung

Suparlan, A. 2013. Total Quality Management (TQM) dengan Kepuasan Pasein. Gresik

Wijayanti, R, B. 2012. Impelementasi Total Quality Management : Studi Pada Puskesmas di Kabupaten Sleman Dengan Sertifikat ISO 9001;2000. Universitas Muhammadiyah, Purworejo 